Mieczystaw Choraży

Centrum Onkologii - Instytut im. Marii Sktodowskiej-Curie, Oddziat w Gliwicach Centrum Badań Translacyjnych i Biologii Molekularnej Nowotworów

\title{
Zjawisko samoorganizacji jako element ewolucji życia
}

\section{THE PHENOMENON OF SELF-ORGANISATION AS AN ELEMENT OF THE EVOLUTION OF LIFE}

The phenomenon of self-organization of matter is well known in physics and chemistry, and for a few decades, we have had evidences that self-organization is an essential element of building structures and functions in living systems. Presumably the process of self-organization has taken place in shaping the chemical prebiotical structures and then in organizing them and forming in complex systems exhibiting the attributes of life. In this essay the author presents the basic features of self-organization, examples of self-organization on chemistry and biology and the basic elements of the functioning of complex systems, where self-organization is the primary agent of action. The phenomenon of self-organization is a new element in the discussion on the evolution of the living world and poses a challenge for the concept of natural selection and genetic factors as the sole causes in the process of evolution.

Key words: self-organization, system, evolution, natural selection.

Od wieków człowiek zadawał sobie pytania: co to jest życie, jak życie powstało, skąd pochodzimy, gdzie podążamy. Za podstawowe atrybuty żywych organizmów zwykle uznaje się następujące właściwości i cechy: podstawową jednostką strukturalną życia jest komórka, materialną podstawą życia są złożone cząsteczki chemiczne i pierwiastki występujące również w otaczającym nas świecie nieożywionym, fenomen 
życia ma cechy wysokiej złożoności, żywe organizmy cechują się zdolnością do wzrostu (narodzenie, rozwój), a ich życie kończy się śmiercią, organizmy żywe mają zdolność do reprodukcji, pod względem termodynamicznym są systemem otwartym, który bezustannie pobiera materię i energię, a wydala ciepło i odpady metaboliczne, który posiada systemy regulacyjne kontrolujące przemianę materii i inne procesy oraz posiada zdolność homeostazy gwarantującą pewną stabilność i niezależność w stosunku do środowiska.

Zwykle wymieniane są trzy główne poglądy na pojawienie się fenomenu życia na Ziemi. Pierwszy pogląd twierdzi, że życie powstało na Ziemi wskutek zadziałania sił ponadnaturalnych lub Boskich. Stwórca życia działał według założonego zamiaru i planu. Drugi, utrzymuje, że prymitywne formy życia przybyły z Kosmosu wraz z materialnymi strukturami wędrującymi we Wszechświecie, czego dowodem mają być m.in. proste cząsteczki organiczne znalezione w meteorytach i pyle kosmicznym (choć nie precyzuje się bliżej gdzie i jak we Wszechświecie życie powstało). Trzeci pogląd wyraża współczesna nauka twierdząc, że życie na Ziemi powstało samorzutnie, poczynając od syntezy prostych cząsteczek chemicznych, które następnie wchodziły w interakcje, i na drodze samoorganizacji rozwinęło się w różnorodne formy. Szacuje się, że proces ewolucji życia na Ziemi zaczął się przed około czterema miliardami lat.

Organizmy żywe w miarę rozwoju stają się coraz bardziej złożone. Skala złożoności (ang. complexity) organizmów żywych zaczyna się od poziomu podstawowego (cząstek i sił podatomowych oraz atomów), następnie obejmuje poziom wyższy (cząsteczek chemicznych), dalej poziomy komórek, tkanek i narządów, wreszcie poziom organizmu i poziom ekosystemów ${ }^{1}$. Złożoność ma strukturę hierarchiczną. U człowieka za najwyższy poziom hierarchicznej złożoności uważany jest mózg i jego złożone funkcje umysłowe, łącznie ze świadomością oraz doświadczeniem historycznym i kulturą.

W drugiej połowie ubiegłego stulecia, sądzono, że wszelkie funkcje i zjawiska w organizmach żywych mogę być wyjaśnione na drodze analizy redukcjonistycznej i sprowadzone do genu. Transmisja z pokolenia na pokolenie informacji zakodowanej w genach plasowała gen na szczycie piramidy życia. Gen stawał się materialnym nośnikiem życia i - jako jednostka poddawana situ selekcyjnemu - gen stawał się także głównym elementem ewolucji.

Tymczasem pogłębiała się nasza wiedza o złożoności fenomenu życia i jego fundamentalnej właściwości - zjawisku samoorganizacji.

M. Chorąży, Złożoność i hierarchia organizmów żywych, „Nauka”3/2011, s. 89-112. 
Proces samoorganizacji uważany jest obecnie za jeden z podstawowych sposobów powstawania hierarchicznej złożoności komórki i ewolucji Nauka żywych organizmów oraz wyłaniania się nowych cech (emergencja). W tym eseju zostaną omówione podstawowe właściwości zjawiska samoorganizacji.

\section{Samoorganizacja i początki życia}

W erze prebiotycznej, przed powstaniem pierwszych form życia i przed początkiem ewolucji biologicznej, panował na Ziemi długi okres, w czasie którego z cząstek podatomowych powstawały proste cząsteczki chemiczne. Procesy te biegły w środowisku wodnym, w płytkich wodach przybrzeżnych i lagunach, gdzie dzięki energii promieniowania słonecznego powstawała swoista „pierwotna zupa”, oraz w głębi oceanów w otoczeniu kanałów wentylacyjnych, gdzie pod wpływem wysokiej temperatury i ciśnienia mogły zachodzić reakcje redukcyjno-oksydacyjne. Powierzchnie nieorganicznej zestalonej materii (skały, glina), mającej strukturę krystaliczną mogły służyć jako katalizatory reakcji chemicznych, prowadząc do syntezy prostych polimerów. Proste cząsteczki chemiczne przekształcały się na drodze reakcji chemicznych w bardziej złożone, a te gromadziły się i przyjmowały różną strukturę wewnętrzną, a gdy ich stężenie osiągało odpowiedni poziom, wchodziły w interakcje między sobą, tworząc zaczątki interaktywnych sieci, przyjmując postać „kropli” (koacerwaty), które następnie odgrodziły się od środowiska samorzutnie powstałą błoną.

$\mathrm{Z}$ chaotycznego zbiorowiska cząsteczek chemicznych będących w stałym ruchu, w dynamicznej interakcji między sobą, stopniowo, w sposób samorzutny wyłaniały się uporządkowane systemy (układy).

Lehn uważa, że powstanie błony komórkowej, a następnie przedziałów błonowych w samej komórce (kompartmentalizacja) „musiały odegrać główną rolę w samoorganizacji złożonej materii i tym samym w ewolucji żywych komórek i organizmów"2. Samorzutnie powstające struktury błoniaste formowały się w pęcherzyki, które zamykały w swoim wnętrzu wodę wraz z reagującymi między sobą prebiotycznymi cząsteczkami chemicznymi mogły w ten sposób tworzyć prymitywne „jednostki życia”, prawzory komórek. Dwuwarstwowe błony fosfolipidowe powstają spontanicznie na granicy faz woda-powietrze i ten proces jest łatwo odtwarzalny w warunkach laboratoryjnych.

J.-M. Lehn, Towards complex matter: Supramolecular chemistry and selforganization, "Proc. Natl. Acad. Sci." 99/2002, s. 4763-4768. 
Proste chemiczne związki metali, a także cząsteczki organiczne, mogą w odpowiednich warunkach spontanicznie samoorganizować się w niezwykle złożone formy i tworzyć wielkie struktury o zdumiewającej architekturze i zupełnie nowych właściwościach ${ }^{3}$. Współczesna nanotechnologia dostarcza wielu przykładów samoorganizacji prostych cząsteczek chemicznych, w wyniku czego powstają twory przestrzenne o zdumiewających formach.

Jean-Marie Lehn ${ }^{4}$ nazywa tę nową dziedzinę nauki chemią supramolekularną. Badacz ten uważa, że od początku ewolucji zachodził proces samoorganizacji materialnych cząsteczek chemicznych w złożone struktury i sieci. Powstawały one w wyniku działania sił elektromagnetycznych, które generowały różnorodność prostych cząsteczek chemicznych, a następnie na nie działały i doprowadziły do powstania nieskończenie wielkiego bogactwa oraz wielkiej ilości cząsteczek. Nagromadzenie cząsteczek chemicznych w określonych niszach ułatwiało ich wzajemny kontakt i oddziaływanie między nimi.

Wspomniane procesy - jak sądzimy - doprowadziły do wyłonienia się protokomórek i następnie komórek prokariontów, które były jedynymi organizmami żywymi na Ziemi przez około 2 miliardy lat ${ }^{5}$. Jakie cząsteczki i pierwotne, proste, funkcjonalne sieci mogły formować się jeszcze przed powstaniem protokomórek, nie wiemy. Jest to pole dla hipotez i spekulacji.

Harold J. Morowitz przedstawił rzeczowe argumenty przemawiające za hipotezą, że pierwsze proste cząsteczki i układy sieciowe związane były z metabolizmem. Uważa on, że kluczowym pierwotnym układem metabolicznym mógł być prototyp i wariant cyklu kwasów trójkarboksylowych, gdyż metabolity i produkty tego cyklu mogły stanowić substraty wyjściowe dla syntezy cząsteczek organicznych np. aminokwasów. Stanley Miller ${ }^{6}$ wykazał, że w warunkach laboratoryjnych naśladujących przypuszczalny stan i skład atmosfery Ziemi w okresie prebiotycznym, z mieszaniny wody, amoniaku, metanu i wodoru, tlenków węgla i cyjanowodoru poddanych wyładowaniom elektrycznym mogą powstawać cząsteczki glicyny, $\alpha$-alaniny, $\beta$-alaniny, kwasu asparginowego i $\alpha$-amino-masłowego - związki występujące w organizmach

3 Por. V. G. Machado, P. N. W. Baxter, J.-M. Lehn, Self-assembley in self-organized systems: a view of programmed metallosupramolecular architecture, "J. Braz. Chem. Soc." 12/2001, s. 431-462.

J.-M. Lehn, Towards complex matter..., dz. cyt.

H. J. Morowitz, The emergence of everything, Oxford - New York, 2002. tions, "Science" 117/1953, s. 528-529. 
żywych. W późniejszych doświadczeniach, Miller, a także inni badacze uzyskali wiele różnych cząsteczek chemicznych występujących Nauka obecnie w żywych organizmach jak: kwas mlekowy, kwas glikolowy, adenina, sarkozyna, kwas bursztynowy, walina, norwalina, prolina, kwas glutaminowy i in.

Trwa spór, która z makrocząsteczek, DNA czy RNA była pierwszym polimerem w erze rodzenia się zjawiska życia. We współczesnych organizmach żywych, DNA posiada właściwości niezbędne dla własnej reprodukcji, jest cząsteczką niosącą „,informację genetyczną”, i stanowi matrycę dla syntezy RNA, co skłania do ustawienia DNA na początku ewolucji życia. Jednakże odkrycie autokatalitycznych właściwości w niektórych cząsteczkach RNA, prowadzących do samopowielania cząsteczek, plasuje RNA w równie czołowej, startowej pozycji ewolucyjnej. Hipotezy o szczególnej roli obu typów kwasów nukleinowych w powstaniu życia są budowane pod wpływem genocentrycznego patrzenia na biologię, gdzie genom jest architektem i pierwotną siłą sprawczą w powstawaniu i funkcjonowaniu różnych form życia, a funkcje na drodze genom - fenotyp mają przebiegać w sposób prostoliniowy.

Manfred Eigen ${ }^{7}$ opracował teorię powstawania układów samoreplikujących, które mogły działać na początku formowania się życia, niezależnych od koncepcji replikacji matrycowej. Szczegółowe omówienie różnych hipotez i teorii dotyczących początków życia na Ziemi przedstawił Stuart A. Kauffman ${ }^{8}$. Teoria replikacji nie-matrycowej oparta jest o zjawisko katalizy chemicznej. Jeśli w sąsiedztwie znajdą się dwie cząsteczki, A i B, które mają taką właściwość, że A katalizuje powstawanie $\mathrm{B}$ z prekursorów $\mathrm{B}$, podczas gdy $\mathrm{B}$ katalizuje powstawanie A z prekursorów A, to powstaje prosty zespołowy autokatalityczny układ (Collectively Autocatalytic Set, CAS). Takie samopowielające się układy powstają i działają w określonych warunkach i można je odtworzyć doświadczalnie. W tym miejscu warto zwrócić uwagę, że sytuacja, gdy dwa elementy (dwie istniejące rzeczy) A i B są uzależnione od elementu (waloru, stanu) C, to taki prosty układ ma już znamiona „organizacji”.

Wspomniane hipotezy dotyczące początków życia, choć bardzo przekonywujące, nie mogą być udowodnione w pełni w warunkach

$7 \quad$ M. Eigen, Selforganization of matter and the evolution of biological macromolecules, "Naturwissenschaften" 58/1971, s. 465-523. 
laboratoryjnych (zwłaszcza dla systemów złożonych), gdyż nigdy nie będziemy w stanie odtworzyć zasadniczego parametru ewolucji, jakim jest upływ czasu. Jednakże od paru dekad rozwija się niezwykle interesująca nauka o zjawisku samoorganizacji w biologii i systemach nieożywionych. Dyskusja o fenomenie samoorganizacji przeniosła się z chemii i fizyki na obszar biologii, a zwłaszcza biologii komórki ${ }^{10}$.

\section{Samoorganizacja w chemii; chemia suprastrukturalna}

Struktury supramolekularne powstają spontanicznie wskutek interakcji cząsteczek chemicznych i działania niekowalencyjnych sił wewnątrzcząsteczkowych ${ }^{11}$. Cząsteczki chemiczne niosą informację na poziomie molekularnym jako immanentną cechę strukturalną, która to informacja jest przetwarzana i wyzyskiwana na poziomie supramolekularnym i podlega algorytmom - swoistym prawom interakcji cząsteczek. Swoista architektura supracząsteczek, zdefiniowana i stabilna, powstaje w procesie gromadzenia cząsteczek, wzajemnego rozpoznania i następnie przez ich asocjacje. Supracząsteczki chemiczne mają wewnętrzną dynamikę, która umożliwia wyłonienienie się złożonej materii posiadającej zdolność do adaptacji w odpowiedzi na czynniki wewnętrzne lub zewnętrzne. W wyniku tych procesów powstają nanocząsteczki. Elementy nanostruktur samoistnie adiustują swoje pozycje tak, aby przyjąć minimum termodynamiczne. Jest to więc przykład, jak drobne cząsteczki chemiczne będące w stanie nieuporządkowanym (chaotycznym) samoorganizują się w wielkie i wysoce złożone struktury.

Chemia supramolekularna wskazuje na istnienie innego rodzaju informacji niż informacja genetyczna, informacji istniejącej w samych syntetycznych cząsteczkach chemicznych, wynikającej z wewnętrznej budowy cząsteczek. W cząsteczkach białka mamy więc również nie tylko informację o liniowym ułożeniu aminokwasów uzyskaną w trakcie przekazu genetycznego, lecz także nową informację i nowe właściwości fizyczne umożliwiające formowanie złożonych struktur przestrzennych oraz interakcje $\mathrm{z}$ innymi makrocząsteczkami.

Historię rozwoju chemii supramolekularnej, jej znaczenie i potencjał dla poznawania zjawiska złożoności, a zatem i aspektów związanych $\mathrm{z}$ fenomenem życia znajdzie Czytelnik w interesującym opracowaniu

10 E. Karsenti, Self-organization in cell biology: a brief history, "Nature Review/ Molecular Cell Biology", 9/2008, s. 255-262.

11 J.-M. Lehn, Supramolecular chemistry: from molecular information towards self-organization and complex matter, "Rep. Progr. Phys.” 67/2004, s. 249-265. 
Jacques Vicens i Quentin Vicens ${ }^{12}$. Autorzy ci przytaczają opinie, że wyłonienie się chemii supramolekularnej, zwłaszcza rozwój jej trze- Nauka ciej fazy, gdzie wprowadzane są koncepcje i słownictwo zaczerpnięte z biologii (samoreplikacja, materia złożona, chemia adaptacyjno-ewolucyjna itp.), włączają tę dziedzinę w nurt dyskusji o materii ożywionej.

Wewnątrzkomórkowe organelle, jony, cząsteczki i makrocząsteczki oraz ich sieci istnieją w środowisku wodnym. Same cząsteczki wody tworzą spontanicznie, a więc również przez samoorganizację, krótkie struktury liniowe lub struktury heksagonalne, labilne i krótko żyjące ${ }^{13}$. Woda i jej formy przestrzenne opłaszczają makroczasteczki, utrzymują je w stanie płynnym i mają wpływ na ich strukturę przestrzenną, mobilność oraz zdolności asocjacyjne. Woda ma zatem istotny udział w procesach samoorganizacji makroczasteczek i jest „macierzą życia”. Ten obszar biologii jest jeszcze mało poznany.

\section{Przykłady samoorganizacji i samoskładania w biologii}

W żywych systemach spontaniczne gromadzenie się małych części $\mathrm{w}$ uporządkowane funkcjonalne systemy i struktury jest zjawiskiem powszechnym ${ }^{14}$.

Cząsteczki chemiczne, wchodzące w proces interakcji i samoorganizacji tworzą między sobą niekowalentne, energetycznie słabe wiązania (siły van der Waalsa, interakcje pi-pi, słabe wiązania wodorowe, wiązania elektrostatyczne i elektromagnetyczne) zorganizowane w struktury o wyższej złożoności i uporządkowaniu niż jej składowe, izolowane komponenty. W odróżnieniu od trwałych wiązań kowalentnych (jonowe, wiązania metali), takie wiązania są nisko energetyczne, ale mają podstawową rolę w funkcjonowaniu systemu - sieci molekularnych w żywej komórce. Proces samoorganizacji jest spontaniczny, dynamiczny i plastyczny. Plastyczność takich układów odnosi się również do struktury i funkcji, i to w wielkiej skali życia: od komórki do populacji (roślin i zwierząt) i do ekosystemów.

Spontaniczne, ale kontrolowane wewnętrznie systemy organizują się poprzez samorozpoznawanie i samoselekcję, przez szukanie najlepszej

12 J. Vicens, Q. Vicens, Emergencies of supramolecular chemistry: from supramolecular chemistry to supramolecular science, "J. Incl. Phenom. Macrocycl. Chem" 71/2011, s. 251-274.

13 J. C. Collins, Molecules and Water in the living cell. Atoms, molecules and water. A creation story. From atoms to the living cell (http://molecularcreation.com/ intro.htm - 2006).

14 B. Bensaude-Vincent, Self-assembly, self-organization: nanotechnology and vitalism, "Nanoethics" 3/2009, s. 31-42. 
termodynamicznie kombinacji między jednostkami składowymi. W żywej komórce interakcję makrocząsteczek białka umożliwia czasowa koordynacja syntezy białek tak, aby partnerskie cząsteczki znalazły się w określonym stężeniu i w określonym przedziale komórki. W tych warunkach motywy (krótkie sekwencje) aminokwasów dwóch różnych cząsteczek białkowych wchodzące w interakcje mogą znaleźć się blisko siebie.

Obok zjawiska samoorganizacji w przyrodzie żywej mamy zjawisko samoskładania (ang. self-assembley). Te dwa zjawiska nie mają ostrej granicy i często są opisywane jedynie jednym terminem: samoorganizacja. Oba zjawiska bazują na tej samej zasadzie: zdolność do samoorganizacji i do samoskładania jest zdeterminowana przez własną wewnętrzną strukturę składowych cząsteczek i oddziaływania między nimi.

Samoskładanie wyróżnia się od samoorganizacji tym, że struktury powstałe wskutek samoskładania (np. samorzutnej polimeryzacji) cząsteczek składowych są raczej statyczne i stabilne, a pod względem energetycznym posiadają najniższy poziom energetyczny. Samoorganizacja odnosi się raczej do interakcji makromolekuł tworzących sieci, które są utrzymywane w stanie dynamicznym dzięki stałej konsumpcji energii z zewnątrz oraz dostawie materiałów odżywczych i wydalaniu odpadów. Tak się dzieje w systemach otwartych, charakterystycznych dla żywych organizmów ${ }^{15}$. Systemy (sieci) powstałe w procesie samoorganizacji mają mieć „siłę kreatywną” (siłę „,vitalną”), tzn. w określonych warunkach mogą samorzutnie indukować nowe konfiguracje i nowe funkcje. Szczegółową dyskusję tych zagadnień znajdzie Czytelnik w opracowaniu Bernadette Bensaude-Vincent ${ }^{16}$ i pracy przeglądowej Marca Kirschnera ${ }^{17}$.

$\mathrm{Z}$ drugiej strony, morfotyczne komponenty komórkowe powstałe w wyniku samoskładania wykazują także zdolność do tworzenia złożonych struktur i architektury komórki, a proces ten nie jest bynajmniej statyczny ${ }^{18}$. Samoskładanie można sobie wyobrazić jako budowanie układanki z części trójwymiarowych (3D), a której ostateczną formę (strukturę) możemy przewidzieć, gdyż jest ona wynikiem sumowania części. Mamy wiele przykładów powstawania uporządkowanych

15 M. Kirschner, M. Gerhart, T. Mitchison, Molecular „vitalism”, “Cell” 100/2000, s. 79-88.

16 B. Bensaude-Vincent, Self-assembly, self-organization..., dz. cyt.

17 M. Kirschner, M. Gerhardt, T. Mitchison, Molecular ,vitalism”, dz. cyt.

18 T. Misteli, The concept of self-organization in cellular architecture, "J. Cell Biol." $155 / 2001$, s. 181-185. 
agregatów i zjawisk samoskładania w żywej komórce. Mikrotubule - mikroskopijne, spolaryzowane rureczki stanowiące wrzecionka po- Nauka działowe i struktury szkieletowe komórki powstają z samoskładania globularnych białek zwanych tubulinami. Przykładem może być też powstawanie błon, pęcherzyków, mikrofilamentów. Podobne zjawiska samoskładania zachodzą w jądrze komórkowym i są związane z transkrypcją, obróbką pre-mRNA i samoskładaniem rybosomów ${ }^{19}$. Czynniki składania pre-mRNA gromadzone są w procesie samoskładania w określonych regionach jądra jako dyskretne, mikroskopijne ziarenka zwane przedziałem czynników składania (ang. splicing factor compartment, SFC). W procesie samoskładania powstają jąderka i ciałka Cajala, a także proces ten zachodzi w trakcie tworzenia kompleksu Golgiego z siateczki endoplazmatycznej itp.

Procesy samoorganizacji/samoskładania można obserwować w warunkach doświadczalnych. Na drodze procesu samoorganizacji, w warunkach doświadczalnych można uzyskać z dużą precyzją np. supramolekularną, pałeczkowatą strukturę helisy z niskocząsteczkowych analogów zasad DNA na podstawie przewidywanych teoretycznych właściwości składowych ${ }^{20}$, można budować błony fosfolipidowe itp.

Znamy też przykłady spontanicznego powstawania struktur biologicznych o dużej złożoności, np. samorzutne powstawanie wirusów, gdy komórka gospodarza nagromadzi w dostatecznej ilości części składowych (białka otoczki wirusa oraz RNA lub DNA). Ich przestrzenny kształt umożliwia samorzutne składanie się bez żadnej dodatkowej instrukcji z zewnątrz w złożoną formę architektoniczną. Samoorganizację wirusa M13 z jego uprzednio izolowanych części składowych i w środowisku pozakomórkowym udowodnili Pil J. Yoo i inni ${ }^{21}$.

W biologii stale zachodzą zmiany struktury przestrzennej biocząsteczek, co zapewnia szersze możliwości interakcji między nimi, a zatem zwiększa potencjał funkcjonalny.

\section{Złożone systemy samoorganizujące}

Samoorganizacja jest to spontaniczne, samorzutne powstawanie uporządkowanej złożonej struktury zwanej systemem lub układem,

19 M. Dundr, T. Misteli, Functional architecture in the cell nucleus. Rev. article, "Biochem. J." 356/2001, s. 297-310.

20 F. Rakotondragany, H. Sleiman, M. A. Whitehead, Hydrogen-bond self-assembly of DNA-base analogues-experimental results, “Canadian J. Chem.”, May 1/2009, Report no. 7114.

21 P. J. Yoo, K. T. Nam, J. Qi i in., Spontaneous assembly of viruses on multilayered polymer surfaces, "Nature Materials" 5/2006, s. 234-240. 
funkcjonującym jako całość, uformowanej z elementów, które początkowo znajdowały się w stanie chaotycznym. Indywidualne składowe systemu (np. makrocząsteczki w komórce) oddziałują między sobą, a ich aktywność jest determinowana lokalnym mikrośrodowiskiem. Aby nastąpiła samorzutna samoorganizacja muszą być spełnione pewne wstępne warunki: składniki (komponenty) systemu muszą zebrać się w odpowiednim miejscu i uzyskać pewną ich koncentrację, tak, aby spontaniczne kontakty między nimi były ułatwione i możliwe. Samoorganizacja jest charakterystyczną właściwością systemów, odpowiedzialną za powstawanie i utrzymanie organizacji systemu oraz jego ewolucję.

Procesy samoorganizacji i systemy powstałe jako wynik samoorganizacji są różnego rodzaju i istnieją w fizyce, chemii, biologii, społecznej organizacji ludzi i zwierząt, a także we Wszechświecie (np. galaktyki). Organizmy żywe wykazują organizację hierarchiczną. Tym terminem określamy taki porządek, gdy jakaś jednostka zajmuje niższy poziom i jest podporządkowana jednostce uplasowanej na wyższym poziomie. W obszarze biologii strukturę i funkcję złożonych systemów możemy rozpatrywać na poziomie subatomowym, poziomie atomów i cząsteczek chemicznych, poziomie komórkowym, tkankowym itd., aż do tych, które funkcjonują na poziomie organizmu i poziomie ekologicznym.

System wykazuje zwykle nowe właściwości, które nie są właściwościami ich części, ani nie są prostą sumą części. Nowe właściwości systemu wyłaniają się na wyższym poziomie hierarchicznym jako wynik interakcji części składowych. Zjawisko to nazywamy emergencją. Właściwości systemu nie można przewidzieć, ani zrozumieć przez analizę redukcjonistyczną i opis części składowych systemu, gdyż właściwości emergentne nie istnieją w częściach, lecz wyłaniają się w miarę wzrostu systemu. Naruszenie stosunków między częściami z niższego poziomu (przez np. usunięcie elementu lub mutację) zaburza właściwości emergentne na poziomie wyższym, ale ostateczny wynik można jedynie określać w kategoriach prawdopodobieństwa, gdyż funkcje w systemie nie przebiegają w sposób liniowy, ani nie wynikają bezpośrednio z właściwości indywidualnych cząsteczek, lecz $\mathrm{z}$ interakcji cząsteczek ${ }^{22}$.

System jest dynamiczny, ulega fluktuacjom w ,poszukiwaniu” własnej niszy, ma swoje trajektorie i swoje preferowane pod względem termodynamicznym pozycje zwane atraktorami. Dzięki stałemu dopływowi energii z zewnątrz systemy żywe są stabilne, ale istnieją z dala

22 A.-L. Barábasi, Z.N. Oltvai, Network biology: understanding the cell's functional organization, "Nature Rev. Genet." 5/2004, s. 101-113. 
od równowagi termodynamicznej, gdyż równowaga oznacza śmierć. Dynamika systemu plasuje je „na krawędzi chaosu”, ale system nie Nauka wkracza w obszar chaosu. Zjawisko życia plasuje się zatem na przejściu fazowym między stanem wysoce uporządkowanym a chaosem.

Miarą chaosu (nieporządku) jest entropia. Żywe organizmy stale generują entropię, ale jej nadmiar ulega rozproszeniu i wydaleniu z systemu. System rozwija się (ewoluuje) w określoną formę samorzutnie, bez zewnętrznego czynnika przyczynowego, czyli samoorganizuje się. System wykazuje cechy autonomii, ale w systemie nie działa jakiś jeden centralny czynnik wewnętrzny jako regulator i koordynator całości, lecz pojawiają się lokalne, kontrolne czynniki sprawcze, rozproszone po systemie, które wynikają z ,wewnętrznej zmienności procesów”. Te ostatnie nazywane są „,szumem” lub przypadkową ,fluktuacją" sytemu. A ponieważ jako efekt ich aktywności system przyjmuje wybiórczą, nową konfigurację, procesy te określa się jako zasadę „porządek przez szum” lub ,porządek przez fluktuację”. Inaczej mówiąc samoorganizacja realizuje się przez poszukiwanie wyboru (opcji) w wewnętrznej fluktuacji. Przypadkowe (losowe) fluktuacje mogą być amplifikowane przez pozytywne sprzężenia zwrotne, dzięki temu możliwe jest powstawanie „nowych konfiguracji systemu i nowości"23. Negatywne sprzężenia zwrotne umożliwiają powrót do stanu wyjściowego. Rozproszenie po całym systemie elementów „kontrolnych” (np. struktura sieci, sprzężenia zwrotne) sprawia, że system jest oporny na perturbacje i uszkodzenia. Molekularne systemy biologiczne wykazują dużą oporność na czynniki uszkadzające, także dzięki redundancji i rozwiniętym mechanizmom samonaprawy, dobrze poznanym w biologii molekularnej.

Lokalnie zapoczątkowane zmiany (np. współoddziaływanie cząsteczek), w wyniku których powstaje nowa forma całości i nowy globalny porządek, znane są w fizyce i chemii. Oto kilka prostych przykładów ${ }^{24}$. Olej w naczyniu o płaskim dnie, podgrzewany od dołu naczynia, wskutek konwekcji ujawnia nową organizację cząsteczek. Cząsteczki oleju układają się w regularny wzór jako tzw. walce lub rolki konwekcyjne Bénarda, wykazujące zorganizowany ruch. W wysokiej temperaturze w kawałku żelaza rozproszone minimagnesy (spiny) mają ruch losowy, bezładny; w procesie chłodzenia spiny samoorganizują się i spontanicznie porządkują układając w jednym kierunku, tworząc silne pole magnetyczne całości. Para wodna w określonych warunkach tempera-

23 F. Heylighen, The science of self-organization and adaptivity, [w:] The Encyclopedia of Life Support System, 2003, s. 253-280. 
tury przybiera formę różnorodnych śnieżynek. Dalszymi przykładami są krystalizacja, powstawanie nanocząsteczek, oscylacje w reakcjach chemicznych i in.

System posiada ,granice”, które oddzielają go od środowiska. Mimo takich granic, zdolność do samoorganizacji pozwala złożonemu systemowi na rozwój i zmiany w jego strukturze i samorzutne przystosowanie do środowiska. Zatem system posiada zdolność do odbierania sygnałów i informacji o stanie środowiska i wykazuje w stosunku do niego zdolność adaptacyjną.

Proces samoorganizacji w biologii nie jest zatem zupełnie „,spontaniczny", gdyż systemy żywe nie są systemami zamkniętymi lecz systemami otwartymi, tzn. odbierają zewnętrzną energię i pożywienie, a wydalają odpady, w tym część energii jako ciepło. Generowanie porządku zmniejsza (eksport poza system) entropię układu. System, przez który stale przepływa energia, który eksportuje i rozprasza entropię, aby utrzymać jego organizację wewnętrzną, Ilya Prigogine nazwał systemem dyssypatywnym ${ }^{25}$. System dyssypatywny rozpada się, gdy dopływ energii ustaje.

System, jak wspomniałem wyżej, choć ma cechy autonomiczne, to jednak reaguje na zmiany zachodzące poza jego granicą. Poparciem tego twierdzenia jest np. obserwowana mikroskopowo spontaniczna samoorganizacja sieci białkowych receptorów w trakcie chemotaksji, zbadana u bakterii w odpowiedzi na subtelne zmiany w środowisku. Bakteria E.coli wykazuje zdolność samorzutnego zgromadzenia i utworzenia nowej złożonej organizacji przestrzennej białek błony i białek podbłonowych (receptorów sygnalnych) w procesie chemotaksji - odpowiedzi na obecność w pobliżu cząsteczek chemoatraktanta, np. glukozy. Proces ten jest dynamiczny, ma charakter okresowy: cofa się lub pojawia ponownie w zależności od sygnału (obecności atraktanta) ze środowiska ${ }^{26}$. Klastry i sieci powstają przez stochastyczny mechanizm samoorganizacji. Nie wiadomo jednak jaki jest mechanizm zapoczątkowania (nukleacji) klastrów, co kontroluje ich wielkość, upakowanie, organizację przestrzenną i lokalizację.

Definicje pojęcia „,samoorganizacja”, podkreślają zwykle swoiste cechy takiego procesu, który prowadzi do powstania złożonych

\footnotetext{
25 G. Nicolis i I. Prigogine, cyt. za: B. R. Johnson, S. K. Lam, Self-organization, natural selection, and evolution: cellular hardware and genetic software, "BioScience" 60/2010, s. 879-885.

26 D. Greenfield, A. L. McEwoy, H. Shroff i in., Self-organization of Escherichia coli chemotaxis network imaged with super-resolution light microscopy, "PloS Biol." 7(6)/ 2009, e1000137, doi:10.1371/journal.pbio.1000137.
} 
systemów. Według Ludwiga von Bertalanffy ${ }^{27}$ termin samoorganizacja określa „tendencję określonych struktur do osiągnięcia względnie au- Nauka tonomicznego - w stosunku do środowiska - stanu stabilnego" (ang. steady state), Jak wspomniano wyżej, w procesie tym, w określonym środowisku, cząsteczki przyjmują zdefiniowaną wewnątrz- i międzycząsteczkową organizację bez ,instrukcji”, bez ingerencji, bez wymuszania i sterowania z zewnątrz.

Encyklopedia of Science and Religion podaje następującą definicję: „Termin samoorganizacja odnosi się do samorzutnego pojawiania się porządku w złożonych procesach”. Inne definicje dodają jeszcze „utrzymanie porządku i stabilnego wzoru relacji między elementami systemu".

Procesy w systemach są nieliniowe, to znaczy, że nie ma proporcjonalnej zależności między przyczyną a skutkiem. W systemach złożonych, a $\mathrm{z}$ takimi mamy do czynienia w biologii, dla poznawania procesów samoorganizacji niezbędny jest rozległy aparat pojęciowy, modelowanie matematyczne, a także zaawansowany warsztat komputerowy. Wiedza uzyskana $\mathrm{z}$ badań nad systemami złożonymi i procesami samoorganizacji będzie miała również wpływ na problemy filozoficzne.

\section{Atraktor, emergencja i łamanie symetrii}

Z procesem samoorganizacji i powstawaniem systemów żywych są związane pojęcia atraktora, emergencji i „łamania symetrii”.

Systemy żywe, dzięki dopływowi energii z zewnątrz są dynamiczne i stale towarzyszą im procesy samoorganizacji. Ich ,trajektorie” podlegają rytmom, oscylacjom, zwrotnym sprzężeniom regulatorowym i są nieprzewidywalne, labilne, choć utrzymane w ładzie.

Makrocząsteczki biologiczne, takie jak białko rozpuszczone w środowisku wodnym komórki, oddziałują między sobą i tworzą niestabilne pod względem termodynamicznym układy. W toku ewolucji, powstające pierwotne, proste sieci makrocząsteczek, mające udział $\mathrm{w}$ określonej funkcji wchodziły w interakcje, następnie powstawały sieci o coraz większej złożoności, zintegrowane, dążące do uzyskania możliwie stabilnego stanu i pewnej „swobody” względem środowiska, jednocześnie adaptując się do jego warunków. Stan ustabilizowany, ale dynamiczny i daleki od stanu równowagi, będący na „krawędzi chaosu" określany jest jako atraktor, lub stan atraktora. Wytrącenie

27 Cyt. za: G. Schwenk, Interlevel relations and manipulative causality, "J. Gen. Philosophy of Science" 37/ 2006, s. 99-110. 
systemu z tego stanu może spowodować wejście jego w obręb działania odmiennego atraktora, który będzie zapewniał systemowi ponowną stabilizację. Systemy nieliniowe o wysokiej złożoności mają zwykle wiele atraktorów.

Stały dopływ energii i konieczność ciągłej adaptacji do warunków środowiskowych (presji środowiska) zmuszają system do ciągłego „uczenia się" jaki stan (atraktor) będzie najbardziej korzystny. Atraktor pomaga w organizacji stabilnego wzoru w obrębie systemu i w utrzymaniu jego funkcji.

Uczenie wymaga zarówno odbioru sygnałów ze środowiska, jak i uruchamiania mechanizmów regulujących odpowiedź. Dla układów biologicznych nie jest możliwe wyliczenie trajektorii i opisanie stanu układu w przyszłości, z czego wynika w praktyce trudność (lub niemożliwość) przewidzenia stanu końcowego układu. Trajektorie układu są trudne do przewidzenia, bo stale podlegają różnym wpływom. Mimo presji środowiska części systemu (np. makrocząsteczki) trzymają się jako funkcjonalna sieć. $Z$ chaotycznego systemu powstaje ostatecznie układ uporządkowany, koherentny, funkcjonujący w obszarze silnie działającego basenu atraktora („basenu przyciągania”). Sporadyczne - spowodowane warunkami zewnętrznymi - fluktuacje, wytrącenia ze stanu równowagi i „wychylenia” uporządkowanego układu powracają do stanu wyjściowego dzięki przyciąganiu „basenu atraktora”. Chwilowe zachwiania równowagi takiego układu są odwracalne, a cały układ jest plastyczny. Jednocześnie uzyskany stan atraktora narzuca dalsze ograniczenie swobody układu, który nie może dowolnie opuścić basenu atraktora.

Pojęcie basenu atraktora Irun Cohen objaśnia przy pomocy następującej metafory ${ }^{28}$. Basen atraktora (region atraktora) można przyrównać do rzeki i jej zlewiska. Fenomen rzeki opisują różne fizyczne warunki i określone składowe. Są to płynąca woda, geologiczne podłoże, nachylenie terenu, źródła, rodzaj dopływów zasilających (dorzecza) i inne elementy tworzące scalony fizycznie i funkcjonalnie basen (zlewisko). Wszystkie te składowe stanowią system utrzymujący dynamikę i funkcję rzeki. Jej żywotność utrzymuje system zasilających strumieni i mniejszych dopływów spływających do basenu dzięki różnicy poziomów między dopływami a rzeką. Basen rzeczny posiada zatem siłę (atraktor) utrzymującą cały układ w ruchu, ale jednocześnie ogranicza „Swobodę" ruchu rzeki: rzeka nie może opuścić swojego basenu.

Jako przykład działania prostego atraktora punktowego podaje się wahadło. Bez względu na to jaki był początkowy ruch wahadła i jakie

28 I. R. Cohen, Tending Adam's garden, San Diego - San Francisco, 2000. 
zakreślało ono trajektorie, końcowym stanem najniższym energetycznie jest punkt, w którym wahadło się zatrzymało. Punkt spoczynkowy Nauka wahadła jest właśnie jego atraktorem.

Redukcjonistyczne podejście głosi, że „całość” (system) jest w pełni zdeterminowany strukturą i zachowaniem „części” (podsystemy, cząsteczki chemiczne). Takie stanowisko jest do przyjęcia jedynie dla systemów zamkniętych. W systemach otwartych, jakimi są organizmy żywe, „całość” jest jednak czymś więcej niż prostą sumą części.

Nie jest możliwe wyjaśnienie i opisanie organizmów żywych wyłącznie w kategoriach fizycznych dotyczących najniższego poziomu hierarchicznego, to jest atomów, cząstek elementarnych i sił rządzących nimi, mimo oczywistego faktu, że są to elementy naszego ciała. Już na następnym, wyższym poziomie (cząsteczki chemiczne) opis przynosi wielkie bogactwo nowej wiedzy, ale ta wiedza także nie opisuje całej złożoności życia. Z każdym wyższym poziomem złożoność systemów żywych wyłania się bowiem jako nowe jakości i nowe właściwości, które nie są w pełni możliwe do zrozumienia na drodze czystej analizy redukcjonistycznej ${ }^{29}$. Stan, w którym złożone systemy biologiczne ujawniają nowe, zasadnicze cechy i właściwości (struktura, funkcja, prawidłowości, zachowanie, informacja, fenotyp), a które nie ujawniały się w częściach z niższego poziomu hierarchicznego (bo ich tam po prostu nie było albo nie ujawniły się) nazywamy emergencją.

Cechą życia jest ład (porządek) i wielkie bogactwo fenomenów emergentnych. „Emergencja jest to samorzutny, spontaniczny rozwój samoorganizacji składowych, których nie można przewidzieć ani objaśnić poprzez analizę tych części. Emergencja jest właściwością wyższych poziomów i nie może być określona ani dedukowana na podstawie właściwości poziomu niższego" ${ }^{30}$. Poszukiwania istoty różnych zjawisk biologicznych (mających cechy zjawisk emergentnych) zmierzają do poznawania coraz to niższych poziomów hierarchicznych, upatrując wyjaśnień w martwych atomach i cząsteczkach chemicznych. Tymczasem zjawiska emergentne poziomów wyższych są „nieredukowalne" do niższych poziomów podstawowych, bo zależności między poziomami są nieliniowe. Nieliniowe procesy, mówiąc ogólnie, są to takie procesy, w których efekty końcowe są nieprzewidywalne i nieproporcjonalne do przyczyny. Cały system jest zatem „wrażliwy” na swój stan początkowy. Michael Polanyi ${ }^{31}$ sądzi, że na wyższych

\footnotetext{
$29 \quad$ M. Polanyi, Life's irreducible structure, "Science" 160/1968, s. 1308-1312.

$30 \quad$ P. T. Macklem, Emergent phenomena and the secrets of life, "J. Appl. Physiol." 104/2008, s. 1844-1846.

$31 \quad$ M. Polanyi, Life's irreducible..., dz. cyt.
} 
poziomach obowiązują nieredukowalne reguły będące nadbudową praw fizyki i chemii działających na poziomach podstawowych. Jakości emergentne są nowymi jakościami, które dołączają się jako dodatkowe zjawisko do procesów fizyko- chemicznych ${ }^{32}$.

Reguła „nieprzewidywalności” musi być brana pod uwagę nie tylko w badaniach naukowych, lecz także w praktyce. Dla przykładu, nie można mieć bezwzględnej pewności ani przewidzieć, jaki będzie końcowy wynik (np. fenotyp choroby) na podstawie analizy na poziomie genotypu, mimo nagromadzenia dużej wiedzy o cechach, właściwościach i regułach działania składowych genomu. Ponadto przewidywanie ryzyka zachorowania jest kategorią odnoszącą się zwykle do populacji i nie sprawdza się w odniesieniu do jednostki.

Właściwości poziomu wyższego możemy jedynie przewidywać według zasad prawdopodobieństwa, a nie dedukować je jako coś pewnego.

Emergencja jest antytezą redukcjonizmu genetycznego głoszącego, że wszystko bierze początek w genie ${ }^{33}$, że gen jest siłą sprawczą działającą w kierunku wyższych pięter hierarchicznych. Nie ulega wątpliwości, że procesy wywołane czynnikiem sprawczym nie biegną jedynie w kierunku „dół-góra” lecz także działają w odwrotnym kierunku, tj. „góra-dół”. Zjawiska emergencji są jeszcze mało zbadane. Nie znamy mechanizmu wyłaniania się emergencji ani konsekwencji, jakie emergencja wywiera na cały system. „Wszystko jest emergencją” - twierdzi tytuł imponującego dzieła Morowitza ${ }^{34}$. Odtworzone zdarzenia od wielkiego wybuchu do powstania Wszechświatów i Kosmosu, oraz od powstania prakomórki do złożonych organizmów żywych i człowieka wraz z jego kulturą i umysłowością stanowią jeden ciągły zjawisk emergentnych.

W przyrodzie obserwujemy struktury symetryczne i niesymetryczne. Symetria w strukturze obiektów przyrody i w sztuce urzeka pięknem. W fizyce symetria znaczy jednolitość, a często brak zdolności do zmian. Mówimy, że obiekt (stan) posiada symetrię, gdy widziany z różnych kierunków jest taki sam. Taką sytuację mamy w stanie początkowym, chaotycznym, homogennym, gdy mamy do czynienia ze zbiorem wielkiej liczby cząsteczek. Porządkowanie systemu przez proces samoorganizacji prowadzi do zniesienia homogenności i powstania

32 Stanford Encyclopedia of Philosophy, Emergent properties, (strona internetowa, wersja poprawiona 23.10.2006).

33 P. Clayton, Hierarchies: the core argument for naturalistic Christian faith, " $\mathrm{Zy}$ gon", March 2008, s. 1-14.

$34 \quad$ H. J. Morowitz, The emergence of everything..., dz. cyt. 
określonych konfiguracji. Powszechnym zjawiskiem w złożonych systemach przyrody żywej jest brak lub obniżanie symetrii, co określany Nauka jako „łamanie symetrii” (ang. symmetry breaking). Towarzyszy ono procesom samoorganizacji i jest istotą „,spontanicznego” powstawania złożoności. Powstanie (wyłonienie się) złożoności i nowego porządku materii jest możliwe dzięki przejściom fazowym (łamanie symetrii) w systemach otwartych, które oddziałują ze swoim środowiskiem. Łamanie symetrii w systemach żywych jest szeroko rozpowszechnione w przyrodzie i zwykle towarzyszy zjawiskom samoorganizacji i osiągnięciu wyższego poziomu jej złożoności.

Vinod Wadhawan ${ }^{35}$ jako prosty przykład łamania symetrii podaje fizyczne przejście fazowe woda-lód. Wbrew pozorom i intuicyjnemu wyczuciu stopień symetrii wody w fazie płynnej jest wyższy niż lodu, choć ten ostatni ujawnia uporządkowanie swojej struktury krystalicznej. Kryształy lodu posiadają symetrię, ale tylko w wymiarze trzech wektorów. Pozycję wszystkich atomów wody w fazie płynnej można opisać używając mniej informacji niż dla opisu pozycji atomów w fazie płynnej. Struktura atomowa cząsteczek wody w fazie płynnej jest taka sama, gdy rozpatrujemy ją wzdłuż nie trzech, ale wszystkich możliwych kierunkach, czyli stopień symetrii wody w fazie płynnej jest wyższy niż w fazie stałej.

Przykładem łamania symetrii wody oraz wyłaniania się nowego porządku i samoorganizacji jest też powstawanie śnieżynek wskutek przejścia fazowego cząsteczek wody. Przypadkowe kolizje cząsteczek wody w wilgotnym powietrzu i niskiej temperaturze prowadzą do wyłonienia się unikatowej struktury kryształków śniegu. Każdy kryształek śnieżynki posiada symetrię sześciopłaszczyznową, ale jednocześnie ma unikatowy kształt. Kształt całego kryształka jest zdeterminowany właściwościami cząsteczek wody, a także na jego strukturę muszą mieć wpływ jeszcze inne czynniki (temperatura, ciśnienie, różne molekularne formy cząsteczek wody), bo różnorodność kształtów śnieżynek jest bardzo bogata. Formowanie śnieżynek jest przykładem złożonych związków regulacyjnych i przyczynowych między poziomami hierarchicznymi. Raz utworzona forma kryształka powoduje, że cząsteczki wody w nim zawarte zostają zniewolone i mogą istnieć jedynie w ściśle określonych miejscach, dozwolonych przez strukturę i kształt kryształka. Zatem całość (kryształek śniegu) narzuca ograniczenia zajmowania określonej pozycji jego części (cząsteczkom wody).

35 V. K. Wadhawan, Complexity explained, (http://nirmukta.com/2009/09/24/ complexity_explained-6-emergence-of-complexity-in-far-from-equilibrium-systems). 
Podobne zjawisko uzależnienia i ,zniewolenia” części przez całość istnieje w układach żywych, gdy system (układ) uzyskuje stan atraktora. Składniki systemu (makrocząsteczki) nie mają pełnej swobody, podobnie jak na wyższym piętrze hierarchicznym składniki komórki nie mają pełnej „swobody” w komórce, a z kolei komórki mają ograniczenia narzucone przez narząd i dalej przez organizm.

W procesie przejścia fazowego woda-lód lub woda-śnieżynka, możemy obserwować ,,spontaniczność” i cechy „,samoorganizacji” w tym sensie, że istota przejścia tkwi w immanentnej właściwości samego układu i zależy jedynie od temperatury i innych warunków otoczenia. W przyrodzie łamanie symetrii idzie w parze $\mathrm{z}$ budowaniem złożoności strukturalnej i funkcjonalnej specjalizacji. Złamanie symetrii jest „pierwszym krokiem w generowaniu złożoności”36.

Przykłady łamania symetrii i dywersyfikacji funkcjonalnej znajdzie Czytelnik w pracy Li i Bowermana ${ }^{37}$. Zjawiska te zachodzą na różnych poziomach: molekularnym, na poziomie struktur subkomórkowych, architektury tkanek i w rozwoju embrionalnym. W komórkach nabłonkowych ujawnienie się polarności szczytowo-podstawowej prowadzi do powstania dwóch płaszczyzn o rozmaitej strukturze i różnych funkcjach. Wystąpienie polaryzacji i asymetrii na powierzchni szczytowej (ang. planar cell polarity) komórek generuje wzór niezbędny dla rozwoju tkanek i narządów. Zaburzenia symetrii architektury komórki jajowej na poziomie molekularnym, np. kumulacja i gradienty stężeń cząsteczek mRNA wytworzonych w czasie dojrzewania komórki jajowej są jednym z podstawowych warunków rozwoju embrionalnego. Prawidłowy podział komórek i napięcie powierzchniowe, a zatem mobilność komórek zależy od właściwości symetrycznych włókienek cytoszkieletu i aktomiozyny. Zaburzenia w procesach łamania symetrii mogą wpływać na kształt złożoności, a zatem mogą odgrywać istotną rolę w zjawiskach patologicznych.

\section{Samoorganizacja czy naturalna selekcja?}

Koncepcja naturalnej selekcji i hipoteza o istotnym udziale czynnika genetycznego (mutacje, dryf genetyczny) w procesie ewolucji życia wymagają uzupełnienia o znaczeniu zjawiska samoorganizacji w ewolucji.

Nagłe skokowe przejście stanu nieożywionego w stan (system) żywy jest zdarzeniem mało prawdopodobnym, który trudno przewidzieć na podstawie praw fizyki. Fenomen życia powstawał jako

\footnotetext{
36 M. Kirschner, M. Gerhart, T. Mitchison, Molecular „vitalism”, dz. cyt.

37 B. Bowerman, R. Li, Symmetry Breaking in Biology, Cold Spring Harbor 2010.
} 
proces wielostopniowy, co pozwalało na uzyskanie wyższego poziomu organizacji ${ }^{38}$. W świecie fizyki zjawisko samoorganizacji wydaje się Nauka być rozsądną hipotezą dla objaśnienia powstawania cząsteczek organicznych i makrocząsteczek, ich stopniowego rozwijania się w systemy posiadające właściwości autokatalizy i reprodukcji, a następnie w wysoce złożone systemy, posiadające atrybuty życia ${ }^{39}$. Fenomen samoorganizacji spostrzeżony i poznany najpierw w chemii i fizyce, a następnie w biologii, stał się niezwykle ważnym dla zrozumienia początków i ewolucji życia ${ }^{40}$.

Od czasów Darwina ogólnie przyjęta koncepcja głosiła, że naturalna selekcja polegająca na eliminowaniu z populacji osobników nieprzystosowanych i ułatwiona prokreacja osobników dostosowanych do środowiska jest podstawowym czynnikiem kreatywnym i siłą sprawczą w ewolucji różnych form organicznych i biologicznej złożoności. Naturalna selekcja była uważana za jedyny czynnik kreatywny w ewolucji, czynnik odpowiedzialny za powstanie złożoności życia i za filogenetyczny wzór powstawania gatunków. Miałaby ona przebiegać „bez końca" jako proces stopniowy, poprzez wiele generacji, i dotyczyć populacji mikrowariantów, uzyskując efekt kumulacyjny (,selekcja kumulacyjna”). Należy pamiętać, że klasyczna teoria ewolucji powstała na długo przed rozwojem biologii molekularnej.

W ubiegłych 60 dekadach, gdy formował się genocentryczny obraz świata żywego neo-darwinizm utrzymywał, że wszystko, włącznie ze złożonością i formą organizmu zostało zaprogramowane w genach. Mutacje genowe i generowanie nowych genów miały być podstawowym mechanizmem kreowania „nowości” i istotą ewolucji. Sam Karol Darwin miał jednak wątpliwości co do wiodącej roli naturalnej selekcji w procesie ewolucji, wypowiadając następującą uwagę: „Jestem przekonany, że naturalna selekcja, była najbardziej ważnym, chociaż nie wyłącznym sposobem modyfikacji" ${ }^{41}$. Mary Jane West-Eberhard w monumentalnym dziele Developmental plasticity and evolution ${ }^{42}$, przedstawiła argumenty i dane doświadczalne wskazujące na ważną

38 R. Pascal, A. Pross, J. D. Southerland, Towards an evolutionary theory of the origin of life based on kinetics and thermodynamics, "Open Biol." (2013) 3. DOI: 10.1018/rsob. 130136.

M. Eigen, Selforganization of matter..., dz. cyt.

E. Karsenti, Self-organization in cell biology..., dz. cyt.

Cyt. za: D. Batten, S. Salthe, F. Boschetti, Visions of evolution: self-organization proposes what natural selection disposes, "Biological Theory" 3(1)/2008, s. 17-29.

M. J. West-Eberhard, Developmental plasticity and evolution, Oxford - New York 2003. 
rolę innych czynników (poza mutacją i naturalną selekcją) w procesie ewolucji. Mutacja jest odpowiedzialna za początek wszystkich nowości w materiale genetycznym, i ewolucja bez mutacji przypuszczalnie uległaby zatrzymaniu, bo wyczerpałaby się zmienność genetyczna. „Ale czym innym jest [problem] początku nowych fenotypów”, pisze West-Eberhard, i dalej autorka uważa, że „najbardziej ważnym inicjatorem nowości ewolucyjnych jest indukcja środowiskowa”. Potencjał ewolucyjny nie tkwi jedynie w fenotypach powstających w wyniku mutacji lecz głównie w cechach genotypowych indukowanych przez środowisko. Złożone struktury (systemy) nie są kodowane przez geny, i zmiany genetyczne nie są wiodące w procesach rozwoju i ewolucji. Ewolucyjne zmiany genetyczne są raczej wtórne, a nie inicjujące, i sprowadzają się do depozytu zmienności genetycznej, który to depozyt w długim horyzoncie czasowym będzie podlegał stopniowym zmianom pod presją selekcji.

Rozwój nauki o zjawisku samoorganizacji i twarde dowody istnienia tego fenomenu w fizyce, chemii i biologii (gdzie mamy wiele przykładów samoorganizacji) jest dużym wyzwaniem dla koncepcji ewolucji Darwinowskiej i neo-darwinizmu. Samoorganizacja systemów złożonych, choć bazuje na komponentach składowych, które specyfikuje genom, sama nie jest programowana przez genom ${ }^{43}$. Biologiczna samoorganizacja jest podstawowym, zupełnie odmiennym od selekcji mechanizmem powstawania złożoności życia. Proces samoorganizacji może być uznany za ,,powszechny mechanizm generowania adaptacyjnego porządku, od poziomu molekularnego do poziomu organizmu"44. Samoorganizujące systemy nie tylko adaptują się do środowiska, ale na bodźce środowiskowe reagują zmianą swej konformacji i funkcji. Zatem zjawisko samoorganizacji głęboko podważa tezę darwinizmu, że selekcja naturalna jest jedynym kreatywnym czynnikiem w ewolucji. Publikacja wymienionych autorów zawiera wiele przekonywujących argumentów wskazujących, że samoorganizacja jest szeroko używana przez organizmy do generowania złożoności także poprzez mechanizm adaptacyjny. Nowy model teoretyczny zwany złożonym systemem adaptacyjnym (ang. Complex Adaptive System, CAS) wypracowany przez zespół teoretyków z Instytutu Santa Fe w Nowym Meksyku (USA), zawiera wiele współdziałających komponentów, które podlegają stałym zmianom zarówno wewnętrznym, powstającym autonomicznie oraz jako skutek współdziałania ze środowiskiem. Środowisko indukuje

43 J. B. Edelman, M. J. Denton, The uniqueness of biological self-organization: challenging the Darwinian paradigm, „Biol. Philos. 22/2007, s. 579-601. 
zmiany fenotypowe i jest czynnikiem inicjującym „nowości” ewolucyjne. Ingerencja środowiskowa w strukturę samoorganizujących Nauka systemów żywych, na poziomie molekularnym, może dotyczyć również komponenty genetycznej systemu generując jego uszkodzenie. Uruchomione w takim przypadku samorzutne procesy naprawcze moga zawodzić. W takim przypadku, system nie może być rozpatrywany jako działający w pełni samorzutnie, i spełnia raczej rolę podległą ${ }^{45}$. Mechanizm adapatacyjny ma być odpowiedzialny za proces „przystosowania" (fitness) do czynników selekcyjnych i presji środowiska ${ }^{46}$.

Problemy „klasycznej” ewolucji na poziomie makroskopowym i populacyjnym są bardzo odmienne od ewolucyjnych procesów ewolucyjnych na poziomie molekularnym.

Relację między naturalną selekcją a zjawiskiem samoorganizacji w ewolucji życia szeroko omawiają m.in. publikacje ${ }^{47}$. Uporządkowany system powstały na drodze samoorganizacji zaistniał najpewniej przed procesem selekcji ${ }^{48}$. W skali czasu zjawisko samoorganizacji wyprzedzało proces selekcji (nie było czego poddawać selekcji). Selekcja i kompetycja o przetrwanie zaczęły działać i wpływać na ewolucję dopiero wówczas, gdy pojawiły się pierwsze reprodukujące się organizmy (pierwsze, żywe „całości”).

Różne propozycje i „wizje ewolucji” można sprowadzić do trzech zasadniczo różniących się między sobą $\left.{ }^{49}: 1\right)$ ewolucją steruje naturalna selekcja, 2) ewolucją steruje samoorganizacja, 3) naturalna selekcja i samoorganizacja w ewolucji są komplementarnymi aspektami tego samego procesu. Proces ewolucji nie mógłby zachodzić bez udziału jednego lub drugiego czynnika. Współczesna wiedza skłania więc do przyjęcia trzeciej propozycji, co można streścić w sentencji: „samoorganizacja proponuje to, co naturalna selekcja będzie realizować”. Według Kauffmana relacja między samoorganizującym się systemem a selekcją polega na tym, że „system żywy istnieje pod ścisłym rygorem na krawędzi chaosu, a naturalna selekcja powoduje osiągnięcie

45 B. R. Johnson, S. K. Lam, Self-organization, natural selection, and evolution: cellular hardware and genetic software, "BioScience" 60/2010, s. 879-885.

F. Heylighen, The science of self-organization..., dz. cyt.

D. Batten, S. Salthe, F. Boschetti, Visions of evolution..., dz. cyt.; B. R. Johnson, S. K. Lam, Self-organization, natural selection..., dz. cyt., P. A. Corning, Synergy and self-organization in the evolution of complex systems, "Systems Research" 12/1995, s. 89-121.

P. A. Corning, Synergy and self-organization..., dz. cyt.

D. Batten, S. Salthe, F. Boschetti, Visions of evolution..., dz. cyt. 
i podtrzymanie tego zrównoważonego stanu"50. Ten pogląd podzielają również inni. Naturalna selekcja utrzymuje system w takim stanie i konformacji, w takiej fazo-przestrzeni, które zapewniają systemowi „największą możliwość dalszej ewolucji”. Szczegółową dyskusję problemu Czytelnik znajdzie w pracach wyżej cytowanych.

$$
\text { *** }
$$

W powszechnym mniemaniu, w biologii nośnikiem informacji są tylko geny i tylko one dziedziczą się i są odpowiedzialne za funkcję, formę i strukturę komórki i całych organizmów. Jest to pogląd uproszczony. Z pokolenia na pokolenie przekazujemy wzór całej architektury komórki, struktury błon, aparatu Golgiego, centrioli, cytoszkieletu, a także wzór złożonej sieci makromolekuł tworzących dynamiczne systemy oraz unikatową zdolność do samoorganizacji. Struktura komórki i jej złożone mechanizmy funkcyjne są dziedziczone, a nie stale i od nowa genetycznie kodowane. Działające w komórce złożone systemy molekularne wykazują zdolność samoorganizacji bez udziału i instrukcji jakiegoś czynnika centralnego. Cząsteczki białka, istotne elementy wysoce złożonej sieci makromolekuł komórki, oprócz informacji uzyskanej w przekazie genetycznym o liniowym ułożeniu określonych aminokwasów uzyskują jednocześnie nową informację i nowe właściwości fizyczne, uprzednio w składowych (aminokwasach) nieistniejące, czyli emergentne.

Redukcjonistyczne podejście głosi, że „całość” (system) jest w pełni zdeterminowany strukturą i zachowaniem „części” systemu. Jednak w biologii analiza redukcjonistyczna, która prowadzi do dokładnego opisu składowych systemu nie pozwala nam (lub pozwala tylko w przybliżeniu), przewidzieć właściwości i opisać stan całego systemu, gdyż właściwości złożonych systemów nie istnieją w ich częściach, ani nie są prostą sumą części. Nowe właściwości ujawniają się (emergencja) jako wynik interakcji części składowych systemu. W organizmach żywych „całość” jest czymś więcej niż prostą sumą części. Zatem opisanie organizmów żywych w kategoriach fizycznych, dotyczących najniższego poziomu hierarchicznego, to jest cząsteczek, atomów, cząstek elementarnych i sił rządzących nimi, mimo oczywistego faktu, że są to elementy naszego ciała, nie jest możliwe.

W organizmach żywych nie ma prostoliniowej lub proporcjonalnej zależności przyczynowej między tym, co dzieje się na podstawowych poziomach hierarchicznych (atomy, cząsteczki) a tym, co obserwujemy 
na poziomie najwyższym (całości). Całość organizmów żywych nie jest redukowalna do części. Geny nie są jedyną siłą sprawczą działającą Nauka w kierunku wyższych pięter hierarchicznych. Również procesy wywołane czynnikiem sprawczym nie biegną jedynie w kierunku „dół-góra” lecz także działają w odwrotnym kierunku, tj. ,góra-dół”.

Istotnym zjawiskiem $\mathrm{w}$ fenomenie życia jest zdolność cząsteczek chemicznych (biocząsteczek) do samoorganizacji. Zjawisko samoorganizacji cząsteczek chemicznych jest znane w chemii supramolekularnej i nanotechnologii, gdzie znajduje również szerokie zastosowanie praktyczne. Zjawisko samoorganizacji polega na samorzutnym powstawaniu uporządkowanej struktury zwanej systemem, złożonym z elementów (części, np. w biologii makrocząsteczek), które w stanie początkowym cechuje brak uporządkowania (chaos). Podstawowym procesem samoorganizacji jest samorzutna interakcja między cząsteczkami, skoro tylko powstaną ku temu odpowiednie warunki wstępne (np. dostateczna koncentracja cząsteczek, temperatura). Ogólny wzór systemu nie powstaje jako skutek centralnego sterowania lecz formuje się jako wynik procesów interakcji cząsteczek w rozproszonych ośrodkach.

Samoorganizujący system posiada dynamiczną strukturę i przejawia różnorodne funkcje, jest zdolny do kreowania „nowości” i interakcji ze środowiskiem. System nie tylko adaptuje się do środowiska, lecz także pod wpływem środowiska może generować konformacyjne i funkcjonalne „nowości”. W tym kontekście, koncepcja ewolucji organizmów żywych oparta na mechanizmach naturalnej selekcji i mutacji genetycznej wymaga co najmniej uzupełnienia i włączenia zjawiska samoorganizacji jako elementu biorącego czynny udział w ewolucji.

Słowa kluczowe: samoorganizacja, system, ewolucja, naturalna selekcja. 